\title{
Geography and resource nationalism: a critical review and reframing
}

\section{Introduction}

Despite the recent reiteration that the control of extractive resources 'lies at the core of modern economic and social development' (Bebbington 2014: 86), it also operates as something 'imagined' rather than just a material reality. One key mode of governance through which this dualism is highlighted is through the discourse and policies of a (re-)emergent 'resource nationalism'. Indeed, an increasing number of contemporary examples abound where the politics of natural resources is articulated in a shifting language of control, national identity, of 'reshoring' offshored resources and the self-determination of pathways to development. All of these are linked, in one way or another, by an increasing trend that the state, as a unit of analysis, is 'gaining primacy in the analysis of resource geographies' (Bridge 2014a: 118). 'Resource nationalism' is one such overt manifestation of this state-resource relation.

Resource nationalism is a term used loosely to describe the tendency for (nation) states to assert economic and political control over natural resources found within its sovereign territory. From this standpoint, much erstwhile understanding rests upon a territorial conceptualisation of the ways in which political power is exercised in controlling the economic distribution of rents derived from natural resource sectors. Yet thinking on resource nationalism has been largely centred on work from the fields of international relations, political science and business which has been quick to warn of its limitations. Much of this work is inspired by the seminal call to 'bring the state back in' to studies of political issue formation (Evans et al. 1985). However, it has largely failed to take seriously the changing political geography of the resources being addressed, in particular the fact that new frontiers of extraction are emerging in ever more extreme spaces. It is argued in this paper that a more useful framework for analysing resource nationalism needs to draw upon geography's treatment of political economy/ecology and the politics of space. This centers resource nationalism around a more complex understanding of the politico-spatial ordering of extractive resources.

In section 2, current understanding of 'resource nationalism' is evaluated, in particular noting the sheer variety of usages and strategies. Here, geography's theorisation of 'hybrid neoliberalisms' (McCarthy 2005) is drawn upon as an initial entry point into a more nuanced understanding of resource nationalism in order to conceptualise the continuum between state and market that defines its policy. In particular, it shows how particular geographies of resource nationalism are represented as more or less 'threatening' to global trade and investment depending on old stereotypes of inefficiency and corruption in the global south.

Following this, section 3 shows the how the contemporary modalities of resource nationalism(s) can be more critically analysed by invoking the relationship between resource politics and space (see Elden 2013b, Bridge 2013). This is a pressing need both in the context of the proliferating emergence of new frontiers of resource extraction through which claims to national resources are made and at a time when humanity's role as a geomorphological 'shaper' is under question ${ }^{1}$. For example, it questions how useful traditionally rigid assumptions made about nationally bordered geographies are in the context of a world where resource frontiers are pushed further afield, offshore and out of

\footnotetext{
${ }^{1}$ This concern with 'shaping' is more apparent than ever at a time where the 'Anthropocene' is under review as a new unit of geological time defined by humanity's impact on the planet. For more on this, see Zalaziewicz et al. 2014.
} 
sight either underground or over the horizon. In this theoretical critique of resource nationalism, the ways in which offshore resources 'out there' become 'landed' both metaphorically (through a discourse of, for example, 'reshoring') and substantively (through the construction of offshore oil, gas platforms and so forth) profoundly matter. The argument that resources are connected in a 'point to point' fashion through capital which 'spans the globe' but does not 'cover it' (Ferguson 2006: 14), tends to reduce the space in-between (including seas, oceans and coasts) to something abstract and 'without dimension' (Steinberg 2013: 163). It also eschews engagement with the space down below, or a third dimension which defines the significance of thinking about resource politics in terms of volume, rather than area (Elden 2013b, Bridge 2013).

Across resource rich states, the discourse of the 'nation' is invoked to create geographies where the imaginaries of resources intersect with notions of rights, identity and citizenship. Cumulatively, these raise several questions of justice and suggest future avenues of enquiry surrounding the coupling of 'resources' and 'nationalism'. These are highlighted in section 4.

\section{Resource nationalism: a 'problem' for neoliberalism?}

Whilst the contemporary re-emergence of the state in resource geographies has been pursued in a critical manner at a broad level (Bridge 2014a), there has been a tendency for more specific attention forwarded to resource nationalism to been conducted through narrowly defined, promarket scholarship. These discursive and substantive engagements conceptually and variously reduce resource nationalism to a language of energy security and economic wellbeing and are read in a timeworn framework of geopolitics and international relations (e.g. Andreasson 2015; Bremmer and Johnston 2009; Stevens 2008). To a degree this should be no surprise as resource politics tends to be conducted with an ontological bias that situates resources (both physically and metaphorically) as a 'geo-political act' (Bridge 2014b). Legal frameworks dictate that resources are nationally bordered and primarily in terms of their political and economic expediency, often serving as de jure and de facto constraints to policy making. Moreover, resources are not seen as just 'there', rather they are imagined to 'belong' to a people circumscribed within the territorial logic of the nation state. For example, every time that a new resource 'discovery' is made, the state is not only quick to assert its national claims but also to do so with reference to other nation states within a particular geo-political ordering. Thus, if we turn to recent empirical instances of resource discoveries, it isn't just that gas is discovered in Tanzania and Mozambique but rather that these countries now 'have as much gas as Kuwait' whilst 'the whole of East Africa-Rwanda, Ethiopia, Kenya-is sitting on geothermal, which is what has transformed Iceland' (Yumkella 2014). By placing resources in taxonomic, pseudo global league tables of resource wealth, such assertions simultaneously suggest the macro-economic possibilities of growth whilst offering the politically expedient projection of 'control', power and geopolitical relevance.

The importance of the theoretical case to better interrogate the 'national' framing of resources should not be understated, and is one way in which geography can foster a deeper understanding of the topic. Yet, it remains the case that the overwhelming foci of studies that have attended to resource nationalism as a discrete object of study have done so from literatures that reinforce rather than critique the fixity of the national imaginary. A greater regard for geography's critical insights into the state of neoliberalism (particularly the attendant emergence of 'post-neoliberalism' and 'neo-extractivism') fundamentally illustrates how resource nationalism should be not be read as the simple opposite of familiar neoliberal imperatives of resource governance but as something which is always hybrid and in flux.

The definitions of resource nationalism that follow are highly divergent, often contingent on political interests and conceptual biases. Taking this as a point of departure, it is assumed that resource 
nationalism, like state sovereignty more generally, is not only a social construction (Biersteker and Weber 1996) but it is also constructed in a number of different ways. Whatever political slant it is given though, it is often assumed that resource nationalism should be seen as the antithesis of economic liberalisation or, as Halina Ward puts it, as 'resource privatism' (Ward 2009). Indeed, this antagonism towards foreign capital (Emel et al. 2011: 71) is a repeated trope amongst free market apologists who see resource nationalism as 'limiting the operations of international...companies, and asserting greater national control over natural resource development' (Stevens 2008: 5). Moreover, this dichotomy is often seen in historical terms as cyclical and naturally vacillating between 'the transfer of ownership of an asset or industry from the private sector to the public sector' and then back again 'from public to private ownership' (Butler 2013; Chang et al. 2010). This 'swinging' in the logic of an economy's structuring highlights an early warning to the mainstream view that 'resource nationalism' is an extreme example of state control and of 'nationalization of the society's wealth of natural resources' (Veltmeyer 2014: 107). It hints at its discursively unstable nature, pitching it as a policy strategy that is always in motion and part of a 'privatization/nationalization pendulum' (Hindery 2013: 22) that is rarely one pole or the other but rather a form of resource governance that is hybrid.

The effects of setting up resource nationalism as a binary between state versus private control serves to reduce the conceptual range of the phenomenon down to a language of economics alone and overlooks the political dimensions of identity and justice. It also negatively differentiates different types of resource nationalism between a global north/south divide. A binary is set up whereby some 'types' of resource nationalism in particular places are seen as worse than others. Thus, it is repeatedly the case that where resource nationalism is said to exist in countries from the global North (Canada, Australia, Norway, Scotland etc.), it is seen as part of a valid, legitimate debate with merit on either side (Bremmer and Johnston 2009). So it is that in Norway, for example, its policies that have heavily taxed petroleum operations are seen as 'a controlled success' (Norwegian Petroleum Directorate 2012) whilst Australia's recent 'resource nationalism' is seen as a strategically defensive move against the potential impacts of burgeoning Chinese investment (Wilson 2011).

Contrary to this rationally constructed debate, when the geographic focus is shifted to states in the global south, and especially in sub-Saharan Africa, it becomes interesting to note how resource nationalism is seen in an overwhelmingly negative light. Rather than being seen as part of a legitimate, if contested, political debate as it is in the north, resource nationalism in the global south is subsumed into a discourse of 'risk' and as a 'barrier' to growth and development. Furthermore, most of this risk is not articulated with inwardly facing reference to a given 'resource nationalist' country's development pathway but rather it is seen as an external risk and barrier to the imperatives of global investment flows. In this way, political economy scholars have asserted that 'the serious issues caused by resource nationalism...are threatening [major International Oil Companies' (IOCs')]...future viability as business entities (Vivoda 2009: 532). Similarly those who see resource nationalism as 'state control or dominance of natural resources' fear a country's 'resulting potential to use this power for political and economic purposes' (Click and Weiner 2009: 784). The 'painfully clear' conclusion in these studies is that such policy approaches 'leave a deep scar in the relationship between the contracting resource producing country and the foreign investor' (Maniruzzaman 2009: 81). Notwithstanding the fact certain policies termed 'resource nationalist' do pose real risks, they are threats largely restricted to economic efficiency and growth.

These intellectual, neoliberal biases towards 'resource nationalism as risk' are also echoed in substantive ways through policy responses on a global scale. For example, the UK government, having identified resource nationalism as a 'threat', commissioned the Department of Environment, Food and Rural Affairs (Defra) to investigate the issue which has thus been conceptualised as 'anticompetitive action designed to restrict the international supply of resources' (Defra 2014). 
Furthermore, when framed as an example of an export restriction, 'hard' action against resource nationalism is often invoked in normative challenges designed to protect the tenets of free tree agreements. One such example in this regard is in the collaborative challenge from the EU, USA and Mexico to the World Trade Organisation regarding China's export restrictions on 'key' raw materials including bauxite, magnesium and zinc (Defra 2014).

Policy interventions such as these are positioned (albeit with a sense of political posturing) as a 'hard' rebuttal to the supposed 'problem' of resource nationalism. However, like the spatially contingent, discursive split between the 'legitimate' resource nationalism of the global north and its 'risky' converse in Africa and the global south described above, this too highlights another geographical binary between 'hard' and 'soft' resource nationalisms. In this dichotomy, 'soft' resource nationalism is manifested in political strategies that comprise changes to regulation, corporate taxation increases and restrictions placed on the export of natural resources. Examples here include, for example, Western Australia's Domestic Gas (Domgas) Policy which ensures that a $15 \%$ proportion of produced liquefied natural gas is reserved for domestic use in order to ensure the state's 'long term energy needs' (Domgas 2012). Similarly, Canada's tightened regulatory climate which has rejected takeovers from corporate giants Petronas and BHP Billiton in the last 5 years has been characterised by ratings agency Fitch as a 'soft' form of a 'rising global trend of resource nationalism' (White and Pooley 2012). Prominent geopolitical critiques argue that such 'soft' resource nationalism should be seen as 'characteristic of OECD countries' who 'generally avoid tearing up existing contracts and using arbitrary tactics' (Bremmer and Johnston 2009: 152).

Indeed, much of this literature establishes a discourse of 'softness' that implies a peculiar geographical imaginary which is somehow specific to countries in the global north. Implicit in this construction is the notion that such 'soft' approaches are somehow more 'benign' than the 'hard' strategies employed by countries in the global south. In contrast to the 'soft' foci on regulation and legislation, 'hard' resource nationalism is used to describe strategies of state control such as cancellation of existing resource contracts, economic nationalisation or 'stringent demands for national shares in natural resource joint ventures' (Ward 2009). On closer inspection however, these 'hard' strategies tend to be located in countries outside the OECD, particularly in Africa, and are characterised in a pejorative discourse of 'threat' and 'spectre' (IRJ 2012; Andreasson 2015:1). From this discursive standpoint resource nationalism 'haunts' the potential for growth and is seen as 'a pernicious doctrine, and its proponents as the political enemy' (Pickel 2003: 107). There have been attempts made to nuance its variety, such as Bremmer and Johnston's widely cited typography which, as well as its 'soft' variety, distinguishes between 'revolutionary', 'economic' and 'legacy resource nationalism' (Bremmer and Johnston 2009). Yet even here, resource nationalism in the global South is viewed in opposition to the imperatives of neoliberal growth and as 'arbitrary and accompanied by little if any compensation or recourse' (Bremmer and Johnston 2009: 150). Notwithstanding the actual differences between the consequences of differing resource nationalist policies for resource management, the discursive split between 'hard' and 'soft' belies particular geographical imaginaries that help to shape global political economy.

Curiously this reductive dichotomy fails to engage critically with contributions from resource geography over the last decade which have stressed the emergence of 'hybrid' or 'post-' neoliberal forms of governance. This, by now, well-formed literature highlights the 'multiple and contradictory aspects of neoliberal spaces, techniques and subjects' that describe the ways in which policy agendas are rarely either 'state-led' or 'market-led' but rather some combination of the two (Larner 2003). Empirical studies elaborate on this point, for example in Mexico where the policy over payments for ecosystem services are shaped by both 'neoliberalism...and concerns about sovereignty over resources' (McAfee and Shapiro 2010: 581). Likewise, in conceptualising the Chilean model for governing resource extraction, Nem Singh suggests that post-neoliberalism is 
constitutive of 'continuity with change', a situation that maintains a business-as-usual marketised governance agenda whilst simultaneously being 'in the midst of the move towards state-controlled resource governance' (Nem Singh 2010: 1413).

Indeed, it can be argued that in different geographies some combination of neoliberal and state-led intervention always co-constitutes and describes resource policy, albeit to varying degrees. Thus it is that rather than being at one end of what Ward terms the 'host state versus investor influence spectrum' (Ward 2009), there is an arguable trend towards policy 'convergence' (Bebbington 2014). Subsequently, just as Bebbington urges critical caution in the use of 'post-neoliberalism' as a distinct mode of extractive governance (Bebbington 2014), so too should similar care be forwarded to the analysis of 'resource nationalism'. In other words, any engagement with the terminology, despite its obvious semantic leanings towards the state as a unit of analysis, often retains an 'inextricable interweaving in practice of analytically separable policy trends' (McCarthy 2005: 998).

Viewing 'resource nationalism' as an example of the way in which the arena of environmental governance itself produces (and contests) neoliberal hybridizations (McCarthy and Prudham 2004) is instructive for nuancing the 'rising tide' of the phenomenon (Dargin 2008, 2015). For example, Ghana's 2013 introduction of far-reaching 'local content law' which is aimed at attaining control for Ghanaians over petro-development through, inter alia, guaranteed equity allowances for Ghanaian firms is characterized in legal terms, as 'resource nationalism' (Government of Ghana 2013; Sauvant 2013: 346). However, at the same time as this post-neoliberal logic is present in the country's petroleum sector, the president of Ghana's Chamber of Mines proffered that 'everything should be done to boost [foreign] investor confidence in the [mining] industry' (Government of Ghana 2012). These examples involve the selective nationalization in some sectors (e.g. hydrocarbons), while at the same time fostering various forms of privatization in others (e.g. minerals or water) and echo what Kaup and Hindery call, in the context of Bolivian pipeline and gas politics, 'neoliberal nationalization' (Kaup 2010; Hindery 2013).

In recent times, scholars have noted increased instances of a shift away from development intervention guided by the Post-Washington Consensus towards 'more productivist and nationallyowned development strategies' (Hickey 2013: 194). By describing the conditions of political restructuring in Latin America, Grugel and Riggirozzi note the retention of market-led growth models in bringing about post-neoliberal welfare changes (Grugel and Riggirozzi 2012). One contemporary and understudied example of this trend can be found in Ecuador's policy of 'La Patria Nueva' (the new nation) which promises to 'leap forward from an economy of finite (material) resources-based economy to an economy based on infinite-based resource: knowledge' (Buen Vivir National Plan 2013). Continuing this more specific focus on resource extraction, important edited volumes have considered the politics and colonial legacies that have come to shape development models of resource extraction in the region (Bebbington 2014; Veltmeyer and Petras 2014).

Much of this literature describes this new role for the state in resource governance as heralding an era of 'neo-' or 'new extractivism' whereby extractive capital mutates in response to the challenges presented to neoliberal modes of extraction. Riffing on the metaphor of the state as a resource actor, Veltmeyer and Petras view Latin America as 'the most important theatre today in the worldwide offensive against neoliberalism...in regard to the formation of a new type of state that marks the end of capitalism as we have known it during the neoliberal era' (Veltmeyer and Petras 2014). However, notwithstanding the fact that a majority of critical attention on the subject of stateled resource policy has been centered on Latin America, other regions (most notably Africa) have, with the exceptions that follow, been largely ignored when the analytical focus is sharpened to focus on the discourse of 'resource nationalism' itself. In this way, there have been compelling arguments made around the relationship between territory, conflict and the identity politics that surround 
resource nationalism in Bolivia and Ecuador (Kohl and Farthing 2012; Perrault and Valdivia 2010). Shifting attention to Asia, recent work has explored the cultural politics of resource extraction in India, in particular noting how coal has become akin to a 'national icon' such that 'coal nationalism' has replaced 'coal colonialism' thus creating a 'coal nation' (Lahiri-Dutt 2014). Likewise, China's investment in gold, chromium and copper mining in the mountains of Tibet has been conceptualized as 'resource nationalism on the roof of the world' (Lafitte 2013). In the African context though, critical analysis of resource nationalism as an example of a 'new politics of development' is still largely lacking (Hickey 2013).

\section{Resource nationalism and space: new frontiers of extraction}

Key political claims of resource nationalist countries are implicitly framed by a control of resources that lie within nationally bounded spaces, of contiguous land masses with physically defined political borders. Here the territoriality, or 'the use of territory for political, social and economic ends' (Agnew 2005: 437) of the resource nationalist legitimates 'national' claims to resources. This is part of a particular resource ecology whose 'natural resources [are conceptualised] as territorial inventories' and whose strategies of resource mapping and appropriation 'seek to produce the "body" of the nation' (Bridge 2014b: 1-2). In conceptualising the resource nationalist state in this way, politicians and their commentators view it as a 'bordered power container' that 'only exist in systematic relations with other nation states' (Giddens 1985: 4). In doing so, such notions fall into a kind of 'territorial trap' and fail to recognise that the spatiality of state power 'cannot be entirely reduced to the template of state sovereignty' (Agnew 2005: 442). In this section, I aim to critique the 'boundedness' and 'spatial coherence' (Painter 2006: 3) inferred by the imaginary of resource nationalism and, by drawing upon new literature, to provoke new ways of imagining the spatial configurations of resources. Indeed, this is crucial not only in a theoretical sense but also in substantive ways because it is precisely the very act of representing the spatial imaginaries of resources which renders them visible and as powerful political objects in and of themselves.

There has been an ongoing turn in political geography which complicates this static, bordered view of state territoriality. This perspective focuses instead on what Alison Mountz terms the 'more ambiguous spatial arrangements or "gray" zones through which sovereign power operates and is produced' (Mountz 2013: 830). It picks up on the related point that the 'national' frame is no longer particularly useful for analysing sovereignty and that the state's 'ability to pursue...developmental policies within their own territories as they see fit' (Wapner 1998: 276) is better seen as a 'relational aggregation of global forces' (Emel et al 2011: 72). In this way, the challenge is to unpack the 'global geography of sovereignty' (Sidaway 2003: 160, emphasis added). In the case of resource nationalism, the questions that this raises are significant. Should, for example, 'national' resources that are 'offshore' be engaged with analytically in the same way as resources that are 'onshore'? How do we make sense of 'resource nationalist' claims to resources over disconnected landmasses, for example Danish claims to ruby extraction in Greenland? Whose 'national' claim counts in contested space such as the Arctic? All of these inquiries, in one way or another, provoke an interrogation of the relationship between space on the one hand and politics on the other. Resource nationalism, at least at a policy level, seeks to reduce this complex relationship to something fixed, static and to locate extractive resources in particular places with a 'peculiar geographic certitude' (Eudaily and Smith 2008: 310). This imaginary seems ever more inappropriate on a planet where, as has been highlighted with reference to oil extraction, geographies of investment seek out access to 'conventional' resources in 'unconventional' places including deepwater, offshore spaces such as the respective Gulfs of Guinea and Mexico (Bridge and Le Billon 2013: 61)2.

\footnotetext{
${ }^{2}$ Bridge and Le Billon (2013) also note that the opposite is true: that investment in resource extraction also proliferates around 'unconventional' resources in 'conventional' locations, such as oil sands in Canada or hydraulic fracturing (fracking) in the USA.
} 
The 'offshore' is a fine example of the way in which sovereignty's ambiguities are exposed. Numerous instances of offshore oil and gas 'discoveries' highlight not only the proliferating reach of global extractive capital on the one hand but also the way in which they can be spatially mobilised in a discourse of resource nationalism on the other. Put another way, the status of being 'offshore' is, from one perspective, an unbundling of sovereignty where 'both the state system and an increasingly integrated market can live comfortably with each other' (Hudson 1998: 933; Palan 2006). Thus, it is found that at the same time that capital is promised freedom and mobility in the offshore, it is simultaneously regulated and conditioned by resource nationalist policies that attempt to project political control over domestic fiscal and economic planning. The offshore exists not as an essentialist space for either the fluid modalities of spatial fix or for the counter-logic of state control promised by resource nationalism but rather as one point in a connection with the onshore. Contemporarily, one example of this relation is the imposition of capital gains taxation as a means of resource nationalism. Here, the state aims to capture tax on the gains made by international resource companies on 'non-resident' transactions where the value is derived from assets based within their jurisdiction. Witnessed in Mozambique (regarding offshore oil and gas), Uganda (in relation to oil) and India's new finance bill that particularly targets structures with 'no substantial commercial purpose' (Government of India 2013: 13), the 'offshore' has emerged as a key battleground for the fiscal and discursive effects of resource nationalism. Put another way, it is not only the case that the 'offshore' resources present a major disjuncture to the idea of a national economy in both conceptual and substantive ways. It is also, as a particular configuration of space, shaped and, mediated by state involvement inclusive of resource nationalist policies. The 'offshore' is still sanctioned by the state, the currencies used to trade in resources are often still 'national' and spatially it remains within the legally defined borders of the state. Thus, whilst remaining cognisant that the 'offshore' includes economies of 'signs and space' (Lash and Urry 1994), it is instructive to remember that it is still 'embedded in the concept of national sovereignty over economic activity, however much they may be disengaged from the territory' (Cameron and Palan 2003: 175).

Just as the conventionality of resource extraction is being challenged, so too should the conceptual frontiers for reading resource nationalism be questioned. Indeed this call is beginning to provoke some important responses from across the social sciences. First, sociologist John Urry has shown how sites of extraction, capital appropriation and responsibility have been shifted out of sight, through both complexity and concealment, and can be seen as crucial features of a new 'offshore' society. The argument's relevance to 'offshore' resources should be clear; namely, that nationalist claims to contemporary discoveries of gas or oil relate to resources that are 'found' sometimes hundreds of miles away from national coastlines. As Urry asserts, 'to go offshore means to go out of view from land, over the horizon, beyond observation' (Urry 2014: 157). If one considers that the horizon is necessarily limited by the bounds of human vision (typically around three miles away) it results that the majority of offshore resources are invisible to human populations in a physical sense. This is in contrast to conventional, landed sites of extraction (mines for example) where, even though the resource may be thousands of feet underground, the surface point of extraction is still visible to those communities who are resettled as a result. Contrary to this however, narratives of resource nationalism render those resources that are unseen, into something politically visible, perceptible and of 'national' concern. Indeed, it is precisely the indiscernible nature of offshore resources that make them politically powerful in so far as their imagined geographies can be constructed through the discourse of resource nationalism as full of economic promise, security and so forth depending on the political climate and imperatives of the time. To this end, the imagined geography of the 'resource nation' can be seen as part of the cultural turn in political economy more broadly where the 'performance' of politics through language is emphasised (Jessop 2004). 
Resource nationalism's analytical reach needs to be extended to better reflect upon the widening and deepening of extractive resource frontiers, which go beyond the 'offshore' yet are still subject to the impacts of national claim making. Indeed the global ordering of geopolitical space is being challenged as advances in both technology and political strategies make possible resource extraction in 'new', 'unbordered' and territorially non-contiguous sites. Much of this work that reflects on contemporary extraction taking place 'beyond the state' focuses on polar geographies, the Artic in particular. A recent special issue in The Polar Journal highlights a new wave of this endeavour with analyses of the regions' identity politics and cultural nationalism to the fore (Dodds and Powell 2013). This builds on Klaus Dodds' interrogation of the Arctic's increasing geopolitical importance where the discourse of 'coastal states' in countries like Iceland is mobilised in order to make particular claims to the region's resources (Dodds and Ingimundarson 2012). At the opposite pole, Dodds and Benwell refer to the interaction between commercial exploration, the spectre of violence, and resource-led nationalism' in describing nationally framed claims to resources in the Antarctic, a legacy of a post-Falklands geopolitical seascape (Dodds and Benwell 2010: 576).

The rise of the resource nationalist state is also being rendered visible in other 'new', more extreme frontiers of extraction such as the deep sea and the moon. In the case of the former, for example, the discursive battle lines are already drawn between apologists for an 'emerging marketplace' who claim that the deep sea floor 'contains four kilograms of gold for every person on the planet' and those who see it instead an ecosystem 'under siege' (Gross 2014: 139). Indeed some states don't view the deep sea as a geopolitical opportunity at all, rather invoking the national imaginary to 'protect' rather than 'control' sovereign resources. For example, Namibia's issuing of a moratorium on all deep sea mining activity in 2013 follows a general admonition from the research community to adopt a precautionary principle against deep sea mining. In this case it is the nation itself that is under threat, and its resources enshrined in its constitution as 'a mirror reflecting the national soul/the identification of the ideals and aspirations of a nation, the articulation of the values bonding its people and disciplining its government ${ }^{3}$. This cultural politics of resource nationalism is similarly repeated in contemporary claims for the moon where US republican politician Newt Gingrich famously pronounced the establishment of a permanent moon base by 2020 which 'will be American'. Whether or not this should be taken as a warning that given regulatory inaction the moon might become the site of a new resource 'scramble', it does at the very least highlight the ways that studies of resource nationalism must keep pace theoretically with the changing politicospatial ordering accelerated by technological change.

Much of the above serves to provoke a more critical theoretical framing of resource nationalism by unhinging the fixity of its national imaginary and by conceptualising resource ecologies in new ways. These include, significantly, a concern with the verticality of resources which, in addition to the imaginary of areal, national territory, functions as a third dimension and creates 'volume' (Elden 2013b). In the context of the 'resource nation', this spatial (re)imagination demands engagement with the new ways in which power circulates and is used to 'secure', control and determine strategies of resource development. States pronounce newly discovered resource wealth in a rhetoric of volumetry: 'barrels of oil' are produced; calculations of 'cubic feet' are used as the basis for revenue sharing negotiations and so on.

The question of who owns and 'controls' the subsurface is also a question of law which needs to make sense of resource claims based on national space and its jurisdiction. Taking up Stuart Elden's question of 'where does the law apply, and where does it cease to apply' (Elden 2013b: 35) is, in the context of resource governance, nowhere more relevant than in the context of contemporary reports of resource nationalism being 'alive and well'. For example, Namibia's current concern with

\footnotetext{
3 Ismael Mahomed, chief justice of Namibia cited in Sachs (2009: 7)
} 
the extraction of 'their' deep seabed must engage with its status as a resource frontier which is managed under the concept of the Common Heritage of Humankind, a principle negotiated before appropriate mining technologies were developed. The instances of negotiations that take place between the politico-legal imperatives of the nation and relevant international frameworks more generally are likely to become more prevalent as technologies used in resource extraction become more advanced. It also suggests that, in thinking through new spatial configurations of resources, the possibility of thinking about time adds an extra dimension to the vertical and areal. Future studies of resource nationalism in particular places might, for example, critically map the genealogy of the 'resource nation', of histories of (uneven) development intervention (Perrault 2013), the legacies of social and environmental injustice, identity politics and symbolic borders. In the concluding section, I suggest some ways in which these insights from geography might enrich such future analyses.

\section{Ways forward in reframing resource nationalism}

Resource nationalism symbolically and materially equates increased national control of extracted resources with the more equitable distribution of their benefits. Yet the discursive mobilisation of the 'resource nation' and its attendant promise of distributive justice simultaneously elides both an engagement with both the plurality of voices across a range of scales and the different dimensions of justice. Resource nationalist claims might emerge rhetorically from national governments but they simultaneously occlude competing claims and identities of a citizenry at the sub-national scale that may not define itself through resources (or be defined) in terms of the 'nation'. In this sense, these struggles over resource ownership and governance are always 'territorialized within national space' (Perrault 2013: 87, emphasis added). Furthermore, the act of highlighting competing historical experience and the identities of resource affectees is to stress the political importance of the inequitable ways that nature and the nation is negotiated. One useful way of framing these concerns is through the lens of environmental and social justice which can explain the uneven distribution of resource costs and benefits, expose the varying levels of influence, access and awareness to the policy making process and emphasise the politics of (mis)recognition at different scales (Sikor and Lund 2009).

One example of this relates to debates over Tanzanian recent gas discoveries which reveals the fault lines in the homogeneity of Tanzania as a 'resource nation'. Here, incipient social mobilization, competing claim-making and activism from numerous groups across various scales is already apparent following predictions that the country will become the world's third largest exporter of natural gas by 2020. Indeed, sabotage and disruption to pipeline infrastructure is enacted on account of the perceived historical legacy of uneven development in the country that situates a marginalised citizenry in the south against the urban elite in the north (Ndwimbwa 2014). Such contentious politics stands in marked contrast to the intimate coupling of resource and nation which was famously part of the Arusha Declaration of 1967. There, in imagining a Tanzanian version of African socialism or ujamaa, the presidential declaration asserted that 'all citizens together possess all the natural resources of the country in trust for their descendants' (Mwakikagile 2007: 448). Yet the critique in contemporary Tanzania, manifested in both localised rioting and discursive sloganeering, frames the relationship between resources and the nation as entirely fractured rather than unified. In particular, the pipeline that connects the gas rich region of Mtwara in the country's south with the urban centre of Dar es Salaam hundreds of miles to the north acts as both a symbolic and material reminder that both natural gas and the justice claims made over it are always dynamic.

Furthermore, other forms of injustice are present exemplified by resource contracts being negotiated in ways that lack transparency or through a politics of misrecognition that represents protests surrounding resource extraction as variously criminal, culturally backward and unpatriotic. 
Taken together, emphasising narratives of justice destabilises the idea of a homogeneous 'resource nation' critiqued by mainstream neoliberal thinking. The politics of justice thus represents an important part of what a critical reading of resource nationalism might look like. Whilst a full empirical examination of this relationship is outside the purpose of this paper, the following points are implicit throughout the discussed literature; First, while the legitimacy promised by state claims to 'national' resources offers a discursive connection to varying modes of justice (including distributive, procedural and as recognition), it often fails to critically unpack competing claims to resources made within a nation's borders. Moreover, given that any justice claims made over natural resources are also inclusive of a politics of identity, the associated point is that these identities also change depending on their scalar focus. On one level resources aren't just something which belong to a state, they are a definitional part of the very biophysical and ideological fabric of the nation state itself. Brazil's recently announced plans to effectively 'nationalize' the Amazon by constitutionally enshrining the rainforest into sovereign law is one example of this. Not only does it exemplify an extreme version of contemporary resource nationalism, it also highlights the ways in which the voices of indigenous groups are marginalised, ignored and not seen as 'Brazilian'. In other words, the distributive justice of resource nationalism is always mediated by the enormous variety of claims to identity and ownership formed around resources and the nation themselves.

In summary, this paper has shown the value of bringing the international relations literature surrounding resource nationalism into conversation with relevant insights from geography that have studied the relationship between extractive resources and the state. In doing so, it complicates overly reductive understandings of resource nationalism and provides a more balanced and better explanatory account. Under this new reading, it suggests that resource nationalism should not be seen as anathema to the imperatives of private-led extraction but rather as something more hybrid. It has shown that, in a world of ever expanding resource frontiers, 'national' borders of extraction are more fluid that those currently presented by mainstream literature with a neoliberal bias. Finally, it argues that the 'one nation' discourse of resource nationalism is misguided as it fails to factor in matters of justice that operate at different scales.

\section{Acknowledgements}

The author is grateful to two anonymous reviewers for their constructive comments. Also thanked are colleagues from the Lancaster Environment Centre for helpful comments on a previous version of the paper. Finally, thanks go to the ESRC and Lancaster University for match funding under an 'ESRC transforming social science' award.

\section{References}

Agnew, J. (2005) 'Sovereignty Regimes: Territoriality and State Authority in Contemporary World Politics,' Annals of the Association of American Geographers, 95(2): 437-461.

Andreasson, S. (2015). 'Varieties of resource nationalism in sub-Saharan Africa's energy and minerals markets'. The Extractive Industries and Society, in press

Bebbington, A. (2014) "Governing Natural Resources for Inclusive Development." In Hickey, S. et al. The Politics of Inclusive Development: Interrogating the Evidence, Oxford: OUP, p. 86 -119

Biersteker, T., and C. Weber, (eds.) (1996) State sovereignty as social construct. Vol. 46. Cambridge: Cambridge University Press

Bremmer I. and R. Johnston (2009) 'The rise and fall of resource nationalism' Survival, 149-158

Bridge, G. \& Le Billon, P. (2013) Oil, Cambridge: Polity

Bridge, Gavin. (2013) "Territory, now in 3D!." Political Geography 34: 55-57.

Bridge, G. (2014a) "Resource geographies II The resource-state nexus." Progress in Human Geography 38(1): 118-130 
Bridge (2014b) 'The Resource Archipelago: spatial aesthetics and resource ecologies' in Arns, I. (ed.) Worlds of Matter, available online at www.worldofmatter.net

British Geological Survey (2014) '3D visualization systems', available online at http://www.bgs.ac.uk/research/environmentalModelling/3dvisualisation.html

Buen Vivir National Plan (2013) 'Good Living National Plan' 2013-2017', available online at:

http://www.planificacion.gob.ec/wp-content/uploads/downloads/2013/12/Buen-Vivir-ingles-webfinal-completo.pdf

Butler, A. (2013) 'Resource nationalism and the African National Congress', Journal of Southern African Institute of Mining and Metallurgy 113: 11-20

Cameron, A., \& Palan, R. (2003). 'The imagined economy: mapping transformations in the contemporary state'. In Brenner, N., Jessop, B., Jones, M., \& Macleod, G. (Eds.) State/space: a reader. London: John Wiley \& Sons, p. 165-184.

Chang R., C. Hevia and N. Loayza (2010) 'Privatisation and Nationalisation Cycles'. NBER Working Paper No. 16126, available online at http://www.nber.org/papers/w16126

Click, R. W., \& Weiner, R. J. (2010). Resource nationalism meets the market: Political risk and the value of petroleum reserves. Journal of International Business Studies, 41(5), 783-803.

Dargin, J. (2015). The Dimensions of Resource Nationalism, London: World Scientific

Dargin, J. (2008). 'The rising tide of expropriation in Venezuela: a look at 21st Century resource Nationalism'. Oil, Gas \& Energy Law Journal (OGEL), 6(2).

Defra (2014) Resource Nationalism, Civil Service Quarterly, available online at https://quarterly.blog.gov.uk/2014/07/15/resource-nationalism/

Dodds, K. and Bennwell, M. (2010) 'More unfinished business: The Falklands/Malvinas, maritime claims, and the spectre of oil in the South Atlantic'. Environment and Planning D: Society and Space 28(4): 571-580

Dodds, K., \& Ingimundarson, V. (2012). 'Territorial nationalism and Arctic geopolitics: Iceland as an Arctic coastal state'. The Polar Journal, 2(1), 21-37.

Dodds, K., \& Powell, R. (2013). 'Polar geopolitics: new researchers on the Polar Regions'. The Polar Journal, 3(1), 1-8.

Domgas (2012) 'Australia's Domestic Gas Security Report 2012' available online at http://www.domgas.com.au/pdf/Alliance_reports/DomGas\%20Report\%202012.pdf

Elden, Stuart (2013b). "Secure the volume: vertical geopolitics and the depth of power." Political Geography 34: 35-51.

Elden, S. (2013a). The birth of territory. Chicago: University of Chicago Press.

Emel J, Huber M .and Makene M. (2011) 'Extracting sovereignty: Capital, territory, and gold mining in Tanzania'. Political Geography 30: 70-79.

Eudaily, S. P., \& Smith, S. (2008). 'Sovereign Geopolitics?-Uncovering the "Sovereignty Paradox'. Geopolitics, 13(2), 309-334.

Evans, P. B., Rueschemeyer, D., \& Skocpol, T. (1985). Bringing the state back in. Cambridge University Press.

Ferguson, J. (2006). Global shadows: Africa in the neoliberal world order. Duke University Press.

Foucault M (1991) Governmentality. In: Burchell G., Gordon C. and Miller P. (eds) The Foucault Effect: Studies in Governmentality, Chicago: University of Chicago Press, p. 87-104.

Giddens, A. (1985) The Nation State and Violence: Volume Two of A Contemporary

Critique of Historical Materialism. Cambridge: Polity.

Government of Ghana (2012) 'Chamber of mines holds forum on resource nationalism', available online at https://www.ghanabusinessnews.com/2013/11/08/chamber-of-mines-holds-forumon-resource-nationalism/

Government of Ghana (2013) L.I. 2204 PETROLEUM (LOCAL CONTENT AND LOCAL PARTICIPATION) REGULATIONS', Available online at http://www.reportingoilandgas.org/wpcontent/uploads/PETROLEUMLOCAL-CONTENT-AND-LOCAL-PARTICIPATIONREGULATIONS2013.pdf 
Government of India (2013) 'The finance bill 2013', available online at http://www.thehindubusinessline.com/multimedia/archive/01380/FinanceBill_1380354a.pdf

Gross, M. (2014). 'The deep sea under siege'. Current Biology, 24(4): 137-139.

Grugel J. and Riggirozzi P. (2012) 'Post-neoliberalism in Latin America: Rebuilding and reclaiming the state after crisis'. Development and Change 43(1): 1-21.

Hickey, S. (2013). Beyond the poverty agenda? Insights from the new politics of development in Uganda. World Development, 43, 194-206.

Hindery D. (2013) From Enron to Evo: Pipeline Politics, Global Environmentalism, and Indigenous Rights in Bolivia. Tucson, AZ: University of Arizona Press.

International Resource Journal (2012) 'Be Mine - Resource Nationalism in Africa', International Resource Journal October 2012, Available online at http://www.internationalresourcejournal.com/features/october12_features/be_mine_resour ce_nationalism_in_africa.html

Hudson, A. C. (1998). Reshaping the regulatory landscape: border skirmishes around the Bahamas and Cayman offshore financial centres. Review of International Political Economy, 5(3), 534564.

Jessop, B. (2004). 'Critical semiotic analysis and cultural political economy'. Critical discourse studies, 1(2), 159-174.

Kaup B. (2010) A neoliberal nationalization? The constraints on natural-gas-led development in Bolivia. Latin American Perspectives 37(3): 123-138.

Kohl B and Farthing L (2012) 'Material constraints to popular imaginaries: The extractive economy and resource nationalism in Bolivia'. Political Geography 31(4): 225-235.

Lafitte, G. Spoiling Tibet: China and Resource Nationalism on the Roof of the World, London: Zed

Lahiri-Dutt, K. (Ed.). (2014). The Coal Nation: Histories, Ecologies and Politics of Coal in India. London: Ashgate

Larner W., (2003), 'Neoliberalism?' Environment and Planning D: Society and Space (21) 509 - 512

Lash, S., \& Urry, J. (1994). Economies of signs and space. Time \& Society, 5(1), 97-102.

Maniruzzaman, A. F. M. (2009). The issue of resource nationalism: risk engineering and dispute management in the oil and gas industry. Texas Journal of Oil, Gas, and Energy Law, 5(1), 79 108.

McCarthy, J., \& Prudham, S. (2004). Neoliberal nature and the nature of neoliberalism. Geoforum, 35(3), 275-283.

McCarthy J (2005) 'Devolution in the woods: Community forestry as hybrid neoliberalism', Environment and Planning A 37(6): 995-1014.

McAfee K and Shapiro E (2010) Payments for ecosystem services in Mexico: Nature, neoliberalism, social movements and the state. Annals of the Association of American Geographers 100(3): 579-599.

Mountz, A. (2013). Political geography I Reconfiguring geographies of sovereignty. Progress in Human Geography, 37(6), 829-841.

Norwegian Petroleum Directorate (2012) 'Embracing Oil in Helgeland' Norwegian Continental Shelf 1: $13-16$

Mwakikagile, G. (2007). Nyerere and Africa: End of an era. Pretoria: Intercontinental Books.

Ndimbwa, M. R. (2014). 'Natural gas conflict in Tanzania and the impacts to the population of Mtwara municipality', Masters thesis, Norwegian University of Life Sciences.

Nem Singh, J. T. (2010). Reconstituting the Neostructuralist State: the political economy of continuity and change in Chilean mining policy. Third World Quarterly, 31(8): 1413-1433.

Painter, J. (2006) 'Territory-network.', Association of American Geographers Annual Meeting. Chicago, USA, 7-11 March 2006

Palan, R. (2006). The offshore world: sovereign markets, virtual places, and nomad millionaires. NY: Cornell University Press.

Perreault T and Valdivia G (2010) 'Hydrocarbons, popular protect and national imaginaries: Ecuador 
and Bolivia in comparative context'. Geoforum 41(5): 689-699.

Perreault, T. (2013). Nature and nation: hydrocarbons, governance, and the territorial logics of "Resource Nationalism" in Bolivia. Subterranean Struggles: New Geographies of Extractive Industries in Latin America. University of Texas Press, Austin.

Pickel, A. (2003). Explaining, and explaining with, economic nationalism. Nations and nationalism, 9(1), 105-127.

Sachs, A. (2009). "Introduction". In The Netherlands Institute for Multiparty Democracy. Writing autobiographies of nations: A comparative analysis of constitutional reform processes. The Hague: The Netherlands Institute for Multiparty Democracy (NIMD).

Sauvant, K. P. (Ed.). (2013). Yearbook on International Investment Law \& Policy 2011-2012. Oxford University Press.

Sidaway, J. D. (2003). 'Sovereign excess? portraying postcolonial sovereigntyscapes'. Political Geography, 22(2): 157-178.

Sikor, T. and C. Lund (eds.) (2009). The Politics of Possesion: Property, Authority and Access to Natural Resources, Chichester: Wiley

Steinberg, P. (2013) 'Of other seas: metaphors and materialities in maritime regions', Atlantic Studies 10(2): $156-169$

Stevens, Paul. (2008) 'National oil companies and international oil companies in the Middle East: Under the shadow of government and the resource nationalism cycle.' The Journal of World Energy Law \& Business 1(1): 5-30.

Swyngedouw, E. (2014). 'Not A Drop of Water...': State, Modernity and the Production of Nature in Spain, 1898-2010. Environment and History, 20(1), 67-92.

Urry, J. (2014). Offshoring. London: John Wiley \& Sons.

Veltmeyer, H., and J. Petras. (2014) The New Extractivism in Latin America. Zed: London

Vivoda, V. (2009). Resource nationalism, bargaining and international oil companies: challenges and change in the new millennium. New Political Economy, 14(4), 517-534.

Wapner, P. (1998). 'Reorienting state sovereignty: rights and responsibilities in the environmental age'. In K. Liftin (Ed.), The greening of sovereignty in world politics. Cambridge: MIT Press

Ward, H. (2009) "Resource nationalism and sustainable development: a primer and key issues." International Institute for Environmental Development 1-58.

White, G and E. Rowley (2012) 'Canada's veto of Petronas deal raises spectre of resource nationalism' Daily Telegraph, Available online at http://www.telegraph.co.uk/finance/commodities/9639184/Canadas-veto-of-Petronas-dealraises-spectre-of-resource-nationalism.html

Wilson, J. D. (2011). 'Resource nationalism or resource liberalism? Explaining Australia's approach to Chinese investment in its minerals sector'. Australian Journal of International Affairs, 65(3): 283-304.

Yumkella, K. (2014) 'There is energy momentum in Africa', Africa Renewal Online at http://www.un.org/africarenewal/magazine/april-2014/there-energy-momentum-africa

Zalasiewicz, J., Waters, C. N., \& Williams, M. (2014). 'Human bioturbation, and the subterranean landscape of the Anthropocene'. Anthropocene, 6, 3-9. 